\title{
Evaluation of Rural Municipalities' (Dehyari) Performance in Realization of Social Sustainability of the Villages Case study of central part of Nimroz city of Sistan
}

\author{
Avaliação do desempenho dos municípios rurais (Dehyari) na realização da \\ sustentabilidade social das aldeias Estudo de caso da parte central da cidade \\ de Nimroz, no Sistão
}

\author{
Abbas Palashl \\ Hamid Ja'farill \\ Hadi Ghanbarzadeh DarbanIII
}

\begin{abstract}
In recent decades, social sustainability has become the center of many researchers and planners' attention. In this regard, one of the main approaches to achieve social sustainability is paying attention to the role of rural municipalities. Regarding the importance of this subject, the current study aimed to evaluate the rural municipalities' performance in the achievement of social sustainability in the Central District of Nimrouz County. The current study is of applied type in terms of objective and it is of descriptive-analytical type in terms of methodology. The data collection instruments were questionnaires and interviews, and the statistical population included the rural households in the central district of Nimrouz County. The data were analyzed by the One-Sample t-test and the variance analysis and multivariable regression were also used to evaluate the rural governor's (Dehtar) performance. The results indicated that rural governors' performance in the social sustainability of the villages under study has managed to grab local villagers' satisfaction and it was at an appropriate level.
\end{abstract}

Keywords: Rural municipality Performance; Rural management; Social sustainability; NimruzCounty

\section{Resumo}

Nas últimas décadas, a sustentabilidade social tornou-se o centro da atenção de muitos pesquisadores e planejadores. Nesse sentido, uma das principais abordagens para alcançar a sustentabilidade social é prestar atenção ao papel dos municípios rurais. Com relação à importância desse assunto, o presente estudo teve como objetivo avaliar o desempenho dos municípios rurais na conquista da sustentabilidade social no Distrito

I Ph.D. Candidate, Department of Geography and Rural Planning, Mashhad Branch, Islamic Azad University, Mashhad, Iran - palash@aftermail.ir

"Assistant Professor, Department of Geography and Rural Planning, Mashhad Branch, Islamic Azad University, Mashhad, Iran - h.jafari@aftermail.ir

I'Assistant Professor of Natural Geography, Mashhad Branch, Islamic Azad University, Mashhad, Iranqanbarzadeh@aftermail.ir 
Central do Condado de Nimrouz. O presente estudo é do tipo aplicado em termos de objetivo e é do tipo descritivo-analítico em termos de metodologia. Os instrumentos de coleta de dados foram questionários e entrevistas, e a população estatística incluiu os domicílios rurais no distrito central do condado de Nimrouz. Os dados foram analisados pelo teste t de uma amostra e a análise de variância e a regressão multivariável também foram usadas para avaliar o desempenho do governador rural (Dehtar). Os resultados indicaram que o desempenho dos governadores rurais na sustentabilidade social das aldeias em estudo conseguiu atrair a satisfação dos moradores locais e estava em um nível apropriado.

Palavras-chave: Desempenho do município rural; Gestão rural; Sustentabilidade social; NimruzCounty 


\section{Introduction}

The conditions for the successfulness of the rural plans depend on three factors as governmental and non-governmental organizations and institutions, public participation, and science and information feedback (ASAYESH, 2009, 38). In this cooperation, the government prepares what the people cannot, and on the other hand, the local people prepare whatever they can in the framework of their local communities and organizations, and decide about it (REZVANI, 2004, 152). The objective of the rural management is a rural sustainable development and these two have commonalities such as 1) provision of basic needs, 2) increasing the food production and security, 3) reducing the poverty, 4) increasing the income, 5) protection of the environment, 6) development of the job opportunities and 7) increasing the participation and self-confidence. The outcome of these principles and objectives, if implemented properly, can be justice, especially spatial justice (FIROOZNIA and EFTEKHARI, 2003, 143). The major objective of rural management is the achievement of a desirable state by the use of potential and actual powers, available in the villages in lines with the situation of the rural society (TALEB, 1997, 6).

The rural regions as the basis of the residential system and national action, play an important role in the national development since the sustainable land development is dependent on the sustainability of the rural spaces in different aspects which can play an effective role in the regional and national development (REZVANI, 2004, 229).

What can be effective in the development is the steps taken for consistent and balanced advancement of the agricultural, industrial, and service activities as well as the optimal settlement of the population, which requires local management that should be able to identify the village problems and adopt the best solution. From the planning point of view, paying attention to rural development and management must be parallel. The rural management in Iran is one of the most important challenges the rural planners face. No factor is as important as the lack of proper perception of rural management and its features as well as the differences between the cities and villages and subsequent differences in managing them, in the failure of rural development plans (CHAMBERS, 1997, 230). With the advent of the Islamic Republic and the great evolutions in the villages, as in the managerial 
sense, the initiation point of the upheavals was enactment of the Law on Organizations, Duties, and Elections of the Country's Islamic Councils in 1996, and then, the enactment of the Law on Establishment of Self-governing Rural Municipalities in the Villages in 1998 by the Fifth Islamic Assembly of Iran, based on which the public and non-governmental institution of Dehyari (rural municipality) was officially introduced to the rural management to, besides filling the existing managerial gap, act as an executive arm of the Islamic councils to realize the sustainable rural development (ALIJANI, 2008, 6).

\section{Statement of Problem}

For scholars, public participation is so credible that development is sometimes considered equal to participation. Therefore, achieving the full-scale rural development without the use of methods in which public participation is not considered as a foundation, is impossible (MOTEILANGROUDI, 2003, 80). The village as the smallest residential unit in the administration division needs a good position in the country's development cycle and better and more precise identification of major social objectives predicted in the top development plans, especially the regional development and civil plans and theorganization of the rural residential areas and space. With a look upon the course of rural management evolution in Iran, it can be found out that in terms of rural society's management, the need for a manager in accordance with the diverse needs and conditions of rural communities, has been always felt, so that the villagers can reach development under supervision of such manager. Such managers have been present from very ancient times (GHORBANI, 2012, 5).

In order to evaluate the successfulness of the rural municipalities in achieving the determined objectives, an evaluation system including 65 technical and scientific indices in 5 domains, has been codified with cooperation of the Office of Performance Evaluation, Inspection and Response to Complaints and Vice-Chancellery for Rural Municipalities and Rural Affairs and Councils offices of the governor-generals. The rural affairs and councils offices of the governors-general, with the cooperation of the county seats, fill in the index forms for each of the related rural municipalities and final scoring of performanceis done 
(THE MUNICIPALITIES AND RURAL MUNICIPALITIES ORGANIZATION OF THE COUNTRY, $2015,6)$.

\section{Review of Related Literature}

KARIMI AND MALEKAN (2014) in a study titled "the rural entrepreneurship: the challenges and opportunities" showed that many rural brokers consider entrepreneurship as a strategy for sustainable rural development.

FARAJIDARABKHANI (2012) in his book titled "the cultural and social development of the village" has concluded that the rural areas of the country, in spite of making up more than $35 \%$ of the total population and the basic facilities and sources that exist in these areas and the great capabilities these areas have, it seems that a part of these capabilities is not optimally put into use due to the challenges and difficulties. Besides, a part is also completely unused.

ARMOON (2012) in a study titled "the position of the modern rural management in development plans, a case study of the villages in Central Shahriar region" concluded that it is necessary to coordinate the Islamic Councils, the village councils and the people's involvement for the development of the villages as much as possible.

MOLAEIHASHTJIN (2012) in a study titled "the proposed model of rural management in Gilan Province" showed that the integrated administrative management is among the features of the proposed model for the small and very small villages as well as the neighboring villages in different sizes, and the integrated management with the directorgeneral performance in the village.

HO, LANG, ET AL. (2017) in a study titled "the local government and justice in provision of the rural infrastructure: cases of rural roads in Chinese villages" showed that the implementation of reformations in the local governments and assigning power and decisionmaking to the people themselves and their elected local authorities have increased the justice and equality in terms of rural road projects in China.

VOLLEY AND CLEVER (2017) in an article titled "the role of local management model in water-saving in the rural areas: does pragmatism occur?" stated that since there are many 
problems in terms of water use in the agricultural sector, the local organization (societyoriented) of water management has defects pragmatically (practically) and academically.

RICHER (2017) in a study titled "the rural social organization as an accepted mediator: the innovative power of connecting rural communities with subregionalnetworks" showed that the rural social organizations transfer the ideas, resources, and support from the external sources to the village and in doing so, more than following the personal interests, they seek their village and rural area's interests.

VAN ASECH ET AL.(2014) in a study titled "rural development and elimination of the dependencies: the evolution driven by the local government changes in Khwarazm, Uzbekistan" showed that formation of different local styles of political rules and regulations leads to chaos and reduction in acceptance of the rule over the villages and fading the expert and specialist-oriented approach.

ROKNEDDINEFTEKHRI ET AL. (2007) in an article titled "a new approach towards the rural management with emphasis on the effective institutions" stated that in the recent decades, the rural planners and managers have come to conclusion that without participation of the local people with the government and the market, achievement of the sustainable development is impossible. On the other hand, the change in managerial methods requires a new approach to effective institutions in the village. As a result, due to dynamism of the rural society, no prescribed prescription would compensate for the defects without the direct participation of the people, government, and the market in the policymaking, management, and planning processes.

ESKANDARINOODEH (2012) in his book titled "the mutual participation and connection between the rural governor, council, and government" states that the expansion of the public participation depends on the institutionalization of the people's participation and connection with the state organizations and the related institutions. In this book, the rural governors firstly get familiar with the concept of the participation and the objective and stages of public participation. Then, the methods of villagers' participation in the administration of the village affairs and rural development are extended. Finally, the factors effective in public participation and the obstacles and limitation of it have been scrutinized. 
AZKIA (2005) in his book titled "An introduction to the rural development sociology" dealt with expression of the social development and transformation in the village. In this book, it has been tried to, besides provision of the theoretical and methodological discussions, express the application of some theories on the rural development in the third world and adapt the development theories with the existing truths in the rural areas of the mentioned societies and explain the differences between the theory and the experimental cases, so that the reader would well understand the mutual relationship between the theoretical and experimental discussions.

SARBARGHI et al. (2015) in an article titled "evaluation of the rural governors' performance in the process of sustainable rural development from the viewpoint of the Binaloud'sTorghabehdistrict's villagers" concluded that in indices in which the villagers' participation has been higher, the satisfaction and successfulness have increased proportionately. Regarding the findings, solutions such as the revision of the rural municipality's duties, reporting to the villagers and informing them, the formation of different local groups, implementation of the profitable plans, and increasing the awareness of the rural communities are effective in higher participation of the villagers.

SHARIFI (2012) in his book titled "what a rural governor should know" expresses that one of the important discussions in the sustainability of the rural municipality institution is the attributes of the rural governor as the village manager to do the assigned tasks. These duties include the creation of mutual trust with the villagers, being disciplined and knowledgeable about his and the council's duties, being participatory, having productionoriented approach, being flexible towards the people and the council, following the village affairs up, belief in the negotiation and discussion, and belief in the different thoughts and tastes.

VOSUGHI (2005) in his book titled "the sociology of the village's cultural and social affairs" has introduced issues and it can be said that this book has been written as a textbook for the rural governors to inform them about the social and cultural angles and the complexities of the rural society.

\section{Methodology}


The current study is of applied type in terms of the objective and of descriptiveanalytical in terms of methodology. The field and library-based methods have been used for data collection.

Cochran's formula has been used to determine the sample size and the number of the questionnaires is 356 . The validity rate of the measurement instrument was approved using the content validity and the opinions of the experts and university professors in the field of geography. In the current study, in order to evaluate the reliability, a primary sample that consists of 25 questionnaires was pretested and the confidence level was calculated using the Cronbach's alphamethod. The result obtained from the Cronbach's alpha for the items of this questionnaire was 0.95 , which is above 0.70 . Both the descriptive and inferential methods have been used in the current study. To analyze the data and information, SPSS software was used and the data were entered in to this software.

\section{Research Findings}

\subsection{Investigation of Descriptive Findings:}

5.1.1 Age Distribution of the Respondents:

The findings show that from among 356 respondents, 25.65 of the total respondents were 20 to $29,30.6 \%$ were 30 to $39,27.5 \%$ were 40 to 49,33 persons which made up 9.3\% of the statistical population were 50 to 59 , and 25 persons which made up the $7 \%$ of the statistical population were above 60 . It can be said the highest frequency belonged to the 30-39 age group.

\subsubsection{Gender Distribution of the Respondents:}

Most of the respondents were male who was $66.9 \%$. Out of 356,118 individuals were female which constitutes $33.1 \%$ of the statistical population.

\subsubsection{Educational Status:}

Out of 356 respondents, $10.1 \%$ are illiterate. These people were mostly old. Around $34.8 \%$ of the respondents had education lower than the diploma who were 124 persons. Among the respondents, 110 had diploma, who were $30.9 \%$ of the respondents. $13.5 \%$ of them had an associate degree, and only $10.7 \%$ of them had bachelor degree. 


\subsubsection{Marital Status:}

Out of 356 respondents, $16.3 \%$ with a frequency of 58 persons were single and $83.7 \%$ with a frequency of 298 persons were married.

\subsection{Investigation of the Residence Status of the Statistical Population in the Area under Study:}

Out of 356 respondents, $1.1 \%$ of them have lived in the area for less than 5 years. 12 persons who were $3.4 \%$ of the respondents, had lived in the area from 5 to 10 years. 50 people also have lived in this area for 10 to 20 years. Finally, 290 persons who were $81.5 \%$ of the samples, had lived in the area for more than 20 years, and it was the highest percentage.

\subsection{Investigation of the Family Status and Record in Village Management (Rural Governor, Member of the Council, the Village Elder):}

Out of 356 respondents, 84 (23.6\%) had stated that themselves or a family member of them had a background of village management with titles such as rural governor, member of the council, or village elder. Among 356 persons, 272 persons (76.4\%) believed that they have not had a managerial background in the village.

\subsection{Evaluation of Rural Municipalities Role in the Development Rate and Improvement of Social of the Villages:}

The One-Sample t-Test has been used to investigate and evaluate the role of rural municipalities in the development rate and improvement of social status in the villages of Nimruz County. According to the findings and with regards to the scale range of 1 to 5 based on the Likert scale, this rate has been evaluated above the utility of index number which is 3 , in all aspects and it is significant at 0.01 alpha level. Also, the numerical mean analysis of the development rate and social status improvement components after the formation of rural municipalities until the present time in the area under study is indicative of the optimal role of the rural municipalities in all social aspects. The research findings indicate that the component of role and performance of the rural municipalities in the formation and increase 
of the spirit of cooperation among the people in the villages of Central Nimruz area with a mean of (4.04) is higher than other components, as the rural municipalities have managed to optimally fulfill their duty and objective of increasing the spirit of cooperation among people in the area under study. the role of the rural municipalities in terms of components such as introducing the poor families to the supportive institutions such as the Imam Khomeini Relief Foundation and Welfare Organization to help them with a mean of 4.00, follow-up of the administrative problems of the villagers and people affairs in the offices with a mean of 3.91, efforts to solve the village problems and issues with a mean of 3.90, and the role of rural municipalities in reducing the local disputes (reduction of the disputes between the different groups in the village and trying to eliminate the grounds of disputes) with a mean of 3.89, are ranked next. The rural municipalities' performance has been very desirable in the mentioned cases. Although the rural municipalities role and performance in the components such as surveying the villagers to identify the village problems, efforts to reduce the local disputes, following the health and medical supports from the villagers, efforts to return the migrants to the village, encouraging the villagers to cooperate in implementation of the plans and surveillance of the hygiene status of the village sites has been also optimal, its performance in the components mentioned above has been more desirable. Among 13 components considered for investigation of the role of rural municipalities in social aspect, the highest mean belonged to the role and performance of the rural municipalities in creation and increase of the spirit of cooperation among the villagers in Central Nimruz area. Generally, it can be said that the rural municipalities' role in the development rate and the improvement of the social status in the villages of Nimruz County has been evaluated (Table 1).

Table 1 - Evaluation of the role of rural municipalities in the development and improvement of the social status by the use of t-statistics

\begin{tabular}{l|c|c|c|c|c}
\hline \multicolumn{7}{c}{ the utility of index number=3 } \\
\hline Component & Mean & $\begin{array}{c}\text { t- } \\
\text { statistics }\end{array}$ & $\begin{array}{c}\text { Significance } \\
\text { level }\end{array}$ & $\begin{array}{c}\text { Mean } \\
\text { difference }\end{array}$ & $\begin{array}{c}\text { 95\% confidence } \\
\text { level }\end{array}$ \\
\hline
\end{tabular}




\begin{tabular}{|c|c|c|c|c|c|c|}
\hline & & & & & $\begin{array}{l}\text { Bottom } \\
\text { limit }\end{array}$ & $\begin{array}{l}\text { Top } \\
\text { limit }\end{array}$ \\
\hline $\begin{array}{l}\text { Creation of } \\
\text { spirit of } \\
\text { cooperation in } \\
\text { the village }\end{array}$ & 04.4 & 171.18 & 000.0 & 039.1 & 93.0 & 15.1 \\
\hline \begin{tabular}{l}
\multicolumn{1}{c}{ Consulting } \\
the villagers \\
about the \\
village \\
problems
\end{tabular} & 86.3 & 492.14 & 000.0 & 857.0 & 74.0 & 97.0 \\
\hline $\begin{array}{l}\text { Efforts to } \\
\text { reduce the } \\
\text { local disputes }\end{array}$ & 89.3 & 785.13 & 0.000 & 89.0 & 76.0 & 02.1 \\
\hline $\begin{array}{l}\text { Follow-up of } \\
\text { the hygiene } \\
\text { and medical } \\
\text { problems in } \\
\text { the village }\end{array}$ & 74.3 & 471.11 & 0.000 & 742.0 & 76.0 & 87.0 \\
\hline $\begin{array}{l}\text { Efforts to } \\
\text { return the } \\
\text { migrants }\end{array}$ & 64.3 & 621.9 & 0.000 & 640.0 & 61.0 & 77.0 \\
\hline $\begin{array}{l}\text { Follow-up of } \\
\text { the } \\
\text { administrative } \\
\text { affairs of the } \\
\text { village }\end{array}$ & 91.3 & 809.14 & 0.000 & 913.0 & 51.0 & 03.1 \\
\hline $\begin{array}{l}\text { Encouraging } \\
\text { the villagers to } \\
\text { participate in } \\
\text { the programs }\end{array}$ & 3.69 & 10.981 & 0.000 & 0.688 & 0.79 & 0.81 \\
\hline $\begin{array}{l}\text { Maintaining } \\
\text { the hygiene of } \\
\text { the village sites }\end{array}$ & 3.69 & 10.372 & 0.000 & 0.688 & 0.56 & 0.82 \\
\hline $\begin{array}{l}\text { Efforts to } \\
\text { solve the } \\
\text { village } \\
\text { problems and } \\
\text { issues }\end{array}$ & 3.90 & 13.688 & 0.000 & 0.896 & 0.56 & 1.02 \\
\hline $\begin{array}{l}\text { Introducing } \\
\text { the poor } \\
\text { families to the }\end{array}$ & 4.00 & 15.005 & 0.000 & 0.997 & 0.77 & 1.13 \\
\hline
\end{tabular}




\begin{tabular}{l|l|l|l|l|l|l}
\hline $\begin{array}{l}\text { supportive } \\
\text { institutions }\end{array}$ & & & & & \\
\hline $\begin{array}{l}\text { Efforts to } \\
\text { maintain the } \\
\text { local traditions }\end{array}$ & 3.66 & 10.261 & 0.000 & 0.663 & 0.87 & 1.02 \\
\hline $\begin{array}{l}\text { Interacting } \\
\text { with the } \\
\text { village's elderly } \\
\text { and elite }\end{array}$ & 3.83 & 11.883 & 0.000 & 0.829 & 0.54 & 0.79 \\
\hline $\begin{array}{l}\text { Efforts to } \\
\text { prevent } \\
\text { villagers } \\
\text { migration }\end{array}$ & 3.72 & 10.543 & 0.000 & 0.719 & 0.69 & 0.97 \\
\hline
\end{tabular}

\subsection{Investigation of the Rural Governors in the Target Villages (33 villages) in terms} of Development and Improvement of the Social Status:

The Post Hoc and Tukey HSD follow-up tests have been used to evaluate the social performance in the target villages (33 villages) and compute the difference in the performance of each rural municipality. In this regard, each of the functions of the rural municipalities has been categorized in the three levels as non-optimal (first category), average performance (second category), and optimal performance (third category) based on the significance levels and the obtained means.

The results of Table 5 shows that there is a significant difference in rural municipalities' performance between the target villages in Nimruz County. In this table, the rate of the rural governors' performance in each village has been provided and categorized under the three non-optimal, average, and optimal status.

Table 2 - The status of the rural governors' performance in the target villages (33 villages) in terms of development and improvement of the social status

\begin{tabular}{|c|c|c|c|c|c|}
\hline \multirow[b]{2}{*}{ Row } & \multirow[b]{2}{*}{ Village name } & \multirow{2}{*}{$\begin{array}{c}\text { Performance } \\
\text { rate }\end{array}$} & \multicolumn{3}{|c|}{ Sustainability } \\
\hline & & & $\begin{array}{c}\text { First } \\
\text { category }\end{array}$ & $\begin{array}{l}\text { Second } \\
\text { category }\end{array}$ & $\begin{array}{l}\text { Third } \\
\text { category }\end{array}$ \\
\hline
\end{tabular}




\begin{tabular}{|c|c|c|c|c|c|}
\hline 1 & Dorwishan & \multirow{7}{*}{ Non-optimal } & 1.54 & & \\
\hline 2 & Gholam Ali & & 1.56 & & \\
\hline 3 & Sharif Abad Saemam & & 2.01 & & \\
\hline 4 & Mansuri & & 2.16 & & \\
\hline 5 & $\begin{array}{l}\text { KadKhodaFaghir } \\
\text { (Lashgari) }\end{array}$ & & 2.30 & & \\
\hline 6 & Piran & & 2.85 & & \\
\hline 7 & KadKhodasafar & & 2.91 & & \\
\hline 8 & DehValidad & \multirow{7}{*}{ Average } & & 3.07 & \\
\hline 9 & Sakhteman & & & 3.12 & \\
\hline 10 & DehKamali & & & 3.45 & \\
\hline 11 & Kachyan & & & 3.70 & \\
\hline 12 & Haj Gholam Ali & & & 3.72 & \\
\hline 13 & PalgiBazi & & & 3.86 & \\
\hline 14 & Deh Isa Sofla & & & 3.87 & \\
\hline 15 & DehBaziSofla & \multirow{10}{*}{ Optimal } & & & 4.02 \\
\hline 16 & $\begin{array}{l}\text { Mohamamd Abad } \\
\text { Adimi }\end{array}$ & & & & 4.02 \\
\hline 17 & DehAlim & & & & 4.14 \\
\hline 18 & Taghazi & & & & 4.14 \\
\hline 19 & Hossein Abad Khajeh & & & & 4.19 \\
\hline 20 & DehnoPoshtAdimi & & & & 4.30 \\
\hline 21 & Akbar Abad Piran & & & & 4.33 \\
\hline 22 & $\begin{array}{c}\text { Deh Noor } \\
\text { Mohammad Dashti }\end{array}$ & & & & 4.37 \\
\hline 23 & $\begin{array}{l}\text { Haji KhodaBakhash } \\
\text { houses }\end{array}$ & & & & 4.37 \\
\hline 24 & Balakahaneh & & & & 4.41 \\
\hline
\end{tabular}




\begin{tabular}{|c|c|c|c|c|}
\hline 25 & Charak & & & 4.55 \\
\hline 26 & Allah Abad & & & 4.60 \\
\hline 27 & DehAllari & & & 4.60 \\
\hline 28 & ShahidMohebaliSarani & & & 4.65 \\
\hline 29 & Mirshah & & & 4.65 \\
\hline 30 & DehShahbaz & & & 4.66 \\
\hline 31 & Deh No Piran & & & 4.72 \\
\hline 32 & DehBaziOlya & & & 4.72 \\
\hline 33 & Hojjat Abad & & & 4.80 \\
\hline \multicolumn{2}{|r|}{ Significance leve } & 0.142 & 0.043 & 0.006 \\
\hline
\end{tabular}

Source: research findings, 2019

Among the 33 villages with rural governors, the best performance of the rural governors belonged to three villages as DehnoPiran, DehBaziOlya, and Hojjat Abad. The weakest performance also belonged to three villages as Dorqishan (Dorwish houses), Gholam Ali, and Sharif Abad Sademam. However, it can be generally said that rural governors' performance in the development and improvement of the social status in Nimruz County's villages has been optimal.

\subsection{Hypothesis Testing:}

It seems the rural municipalities' performance has been socially optimal.

Table 3 - The overall results of the hypothesis testing in terms of rural municipality's social performance

\begin{tabular}{l|c|c|r|r|r|r|r}
\hline Factors & $\begin{array}{l}\text { Mea } \\
\mathbf{n}\end{array}$ & $\begin{array}{c}\text { Standar } \\
\mathbf{d} \\
\text { deviation }\end{array}$ & $\begin{array}{c}\text { Media } \\
\mathbf{n}\end{array}$ & $\begin{array}{c}\text { Lowe } \\
\mathbf{r} \text { than } \\
\text { median }\end{array}$ & $\begin{array}{c}\text { Equ } \\
\text { al to } \\
\text { median }\end{array}$ & $\begin{array}{c}\text { Abov } \\
\mathbf{e} \\
\text { median }\end{array}$ & $\begin{array}{c}\text { Significan } \\
\text { ce level }\end{array}$ \\
\hline $\begin{array}{l}\text { Rural } \\
\text { municipalities } \\
\text { social } \\
\text { performance }\end{array}$ & 3.81 & 1.037 & 4.15 & 112 & 133 & 111 & 0.000 \\
\hline
\end{tabular}


The descriptive tests and analyses have been used to evaluate the research hypothesis and the rural governors' performance in terms of the social aspect in Nimruz county's villages.

According to the findings in tables 3 to 6 , evaluation of the overall performance of the rural municipalities in terms of social aspect (3.81) indicated that the social performance of the rural governors has been evaluated above the utility of index number which is 3 , and it is significant in at 0.01 alpha level. The numerical mean analysis of the development rate and social status improvement components after the formation of rural municipalities until the present time in the area under study is indicative of the optimal role of the rural municipalities in all social aspects. The evaluation of the medians of the responses of the rural municipality's social aspect performance showed that this value has been 4.15 , as from among a total of 356 respondents, responses of 112 persons have been lower than the median. A number of 133 responses out of the total statistical population were equal to the median, and 111 responses were above the median, which is indicative of the proper responses of the respondents in terms of the social performance of the rural municipalities. The significance level of the rural municipalities social performance in the villages of Nimruz County of Sistan City has been at the optimal level of 0.000 , which is indicative of the property of the test's significance level, as the rural governors' performance in terms of the improvement of the social conditions of the villages in Nimruz County has been optimal. Therefore, it can be said that rural municipalities' performance leads to the improvement of the social conditions of the villages in Nimruz County of Sistan City. Thus, it can be said that the research hypothesis has been approved.

\section{Discussion and Conclusion}

In the international literature, the interest in development and improvement of the rural societies in economic and social aspects have been increasingly growing and it has been considered as a strategy to improve the living conditions and the most important 
solution to solve the villagers' problems. It significantly organizes the social communities' livelihood. The evolution in rural areas of the developing countries is especially important since these areas play an important role in the social development of such countries. The development of these areas and the achievement of development in these areas are among the basic objectives of rural development plans of the countries. Among the main axes of the governments' policies to achieve the rural development is the use of different tools and various measures that are implemented and paying attention to the development of the local communities and participation of the local players with a process-oriented approach to the sustainability of the decisions at different levels to maintain the villages.

The research findings indicate that the component of role and performance of the rural municipalities in the formation and increase of the spirit of cooperation among the people in the villages of Central Nimruz area with a mean of (4.04) is higher than other components, as the rural municipalities have managed to optimally fulfill their duty and objective of increasing the spirit of cooperation among people in the area under study.the role of the rural municipalities in terms of components such as introducing the poor families to the supportive institutions such as the Imam Khomeini Relief Foundation and Welfare Organization to help them, follow-up of the administrative problems of the villagers and people affairs in the offices, efforts to solve the village problems and issues, and the role of rural municipalities in reducing the local disputes (reduction of the disputes between the different groups in the village and trying to eliminate the grounds of disputes) are ranked higher than other components, and the rural municipalities' performance has been very desirable in the mentioned cases.

\section{References}

Alijani, Abbas. Dehyari from the Beginning to the Present, Journal of Research, Education and Extension No. 26, Office of Rural Studies and Planning of Municipalities and Rural Municipalities of Iran, 2008.

Armon, A. the Position of Modern Rural Management in Development Plans, National Conference on Rural Development, 2012.

Chambers, Robert. Rural Development Prioritizing the Poor, Translated by MustafaAzkia, 
University of Tehran Press, 1997.

Faraji Darabkhani, Mohammad. Cultural and Social Development of the Village, Publications of Municipalities and Rural Municipalities, 2012.

Firouznia, Ghadir, RokneddinEftekhari, Abdul Reza. The Position of the Village in the National Development Process from the Viewpoint of the Experts, Tehran Institute of Rural Development of Iran, 2003.

Ghorbani, Ali. Introduction to a set of the Village and Rural Municipalities rules and regulations (what a rural governor should know) Publications of Municipalities and Rural Municipalities, 2012.

Ho, long. Local Government and Rural Infrastructural Delivery in Nigeria, International Journal of Academic Research in Business and Social Sciences. 4(4), 56-77, 2017.

Karimi, SeyyedHadi, Malekan, Ahmad. A Study of Rural Management in Iran with Emphasis on the Role of Councils and Dehyari, Dehyahirs Monthly. 35, 2014.

Molaei, Hashtjin. Proposed Model and Model of Rural Management in Guilan Province, National Conference on Rural Development, 2012.

Motiei Langroodi, Seyyed Hassan. Rural Development Planning with Emphasis on Iran, Jahaddaneshgahi Press, 2003.

One ich. (). Agroecology territories: places for sustainable agricultural and food systems and biodiversity conservation, Agrroecoly and Sustainable Food Systems. 40(2), 132-144, 2014.

Organization of Municipalities and Rural Municipalities of Iran. Code of Conduct for Assessment of Rural Municipalities, 2015.

Rezvani, M.R. Introduction to Rural Development Planning in Iran, Tehran. Ghums Publishers, 2004.

Richard, P, Kama. A. A Study of Indigenous Knowledge and Its Role to Sustainable Agriculture in Samoa, Ozean Journal of Social Sciences. 3(1), 65- 66, 2017.

Taleb, Mehdi. Rural Management in Iran, Tehran University Press, 1996.

ValliZeijl-Rozema, A., Martens, P. An adaptive indicator framework for monitoring regional sustainable development: A case study of the INSURE project in Limburg, The Netherlands. Sustainability: Science, Practice and Policy. 6(1), 6-17, 2017. 